\title{
Electrochemical Determination of Antioxidant Activity of New 4-Thiosubstituted Quinoline Derivatives with Potential Radioprotecting Properties
}

\author{
Maryna M. Kornet ${ }^{1}$, Oleksandr A. Brazhko ${ }^{1}$, Mykhailo P. Zavhorodniy 1,*(D), \\ Volodymyr V. Tkach 2,3,*iD, Olga S. Kruglyak ${ }^{4}$, Yana G. Ivanushko 5,* (D), Sílvio C. de Oliveira ${ }^{3, *}$ \\ Petro I. Yagodynets ${ }^{1}$

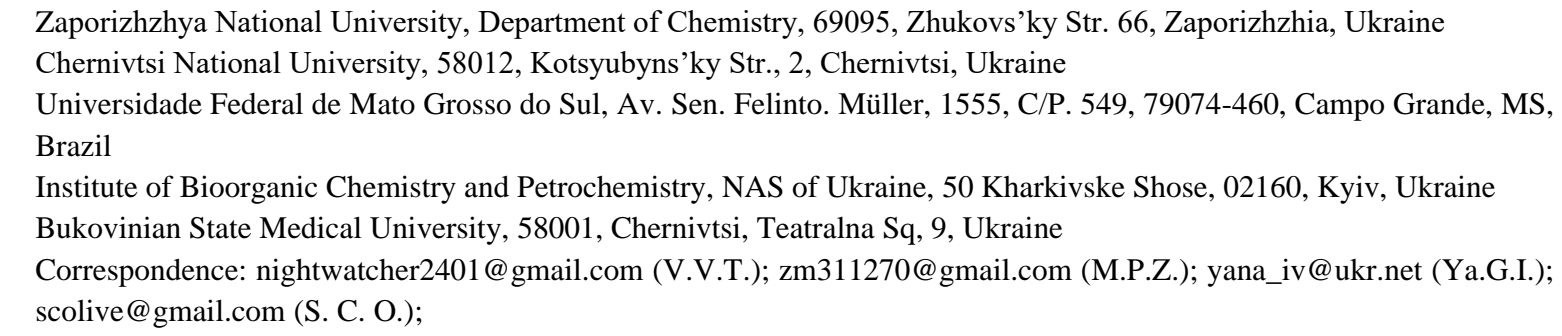

Received: 24.07.2020; Revised: 28.08.2020; Accepted: 30.08.2020; Published: 2.09.2020

\begin{abstract}
The 4-thioquinolinic derivatives with potential antioxidant activity have been investigated. Their research antioxidant activity on two models has shown that they are effective traps of such free radicals as hydroxyl-ions and superoxide-anions, which confirms the compatibility of these derivatives for radioprotector activity investigation.
\end{abstract}

Keywords: quinoline-4-thiol; virtual screening; antioxidant activity; radioprotectors.

(c) 2020 by the authors. This article is an open-access article distributed under the terms and conditions of the Creative
Commons Attribution (CC BY) license (https://creativecommons.org/licenses/by/4.0/).

\section{Introduction}

Nowadays, ionizing radiation may be considered one of the main dangerous factors. One of the cases of the post-irradiation death of the animals is the damage of the DNA molecules. Most to the DNA modification processes (60-80\%) is caused by reacting oxygen species (ROS) generated during the water radiolysis. The ROS also leads to dangerous metabolic processes like free radical lipid peroxidation and oxidative protein modification [14]. So, the radioprotective action may be realized by means of high anti-radical activity with certain ROS [5]. It is possible to reproduce the processes occurring during the water radiolysis by electrochemical methods like impulse voltammetry.

The search for new effective and less-toxic bioactive molecules includes the research of natural and synthetic compounds, among which the quinolinic derivatives take important part as synthons and biologically active compounds with a different mechanism of action [612]. The most prominent quinoline derivatives in the aspect of radioprotection are 4-thiol substituted quinolines, which are effective radical traps [13].

The investigation of radioprotection activity requires much data, animal material, and time. So, in order to enhance the efficiency of these experiments, it's necessary to use theoretical PASS-screening for anti-radical, antioxidant, and membrane-protecting activities and also to realize some in vitro experiments of antioxidant and anti-radical activities. These 
experiments include the adrenaline oxidation inhibition evaluation and impulse voltammetry. The use of an impulse voltammeter lets us clarify the mechanism of antioxidant action of the investigated compounds and test them simultaneously in order to compare their activities within a short period of time.

The goal of this work is the selection of potent antioxidants, and radioprotectors among the novel 4-thiol substituted quinolines by means of virtual screening and in vitro investigation of anti-radical and antioxidant activity of these compounds as radioprotectors.

\section{Materials and Methods}

Synthesis and physicochemical properties of the compounds (1a-x, 2a-x, 3a-f) have been described by us in the works $[14,15]$.

The individualities of the synthesized compounds were controlled by thin-layer chromatography. The composition of these compounds was verified by NMR spectrum.

The chromatographic investigation was realized on Sorbfil plates (obtained from «Sorbpolimer», Ukraine, UV-254) in different solvent systems. The chromatograms were manifested by using UV irradiation.

The antioxidant and radioprotective activity was conducted online by the use of the PASS (Prediction of Activity Spectra for Substances) program. The activity prediction was characterized by activity $(\mathrm{Pa})$ and inactivity $(\mathrm{Pi})$ probability calculations, being made by analysis of the formula of the compound and was based on the analysis of the formula of this compound and analysis of the "structure-activity" correspondence database [16].

In order to conduct the antioxidant activity (AA) investigation, using in vitro techniques, it is possible to use the method of adrenalin oxidation inhibition, based on the ROS inhibitions by the tested compounds. A non-enzyme reaction of adrenaline oxidation to adrenochrome is realized in alkaline media in the presence of the oxygen anion-radical $\mathrm{O}_{2}{ }^{-}$. In the biological system, this process is conducted by superoxide-dismutase, but in vitro, the ROS are generated in a different manner, and this reaction may be used in order to evaluate the AA of the biologically active compounds [17].

During the adrenaline-inhibition test, to a spectrophotometer (ray length $10 \mathrm{~mm}$ ) cuvette $2 \mathrm{ml}$ of $0,05 \mathrm{M}$ sodium carbonate buffer $(\mathrm{pH} 10,2)$ with the addition $3 \cdot 10^{-4} \mathrm{M}$ of $\mathrm{Na}_{2}$ EDTA was added. $0,1 \mathrm{ml}$ of the solvent for the test compound was added to the reference solution. Yet to the analytical probe, the solution of the investigated compound has been added in the volume of $0,1 \mathrm{ml}$ in the final concentration of $125 \mathrm{mM}(25 \mathrm{mM})$. The reaction was launched by an introduction of $0,4 \mathrm{ml} 0,01 \mathrm{M}$ adrenaline hydrochloride into the system. It was realized by the temperature of $35-36{ }^{\circ} \mathrm{C}$ for 3 minutes. AA of the compounds was detected spectrophotometrically by the inhibition degree of adrenaline autooxidation into adrenochrome, which is colored. The wavelength used was equal to $484 \mathrm{~nm}$, and the inhibition degree was calculated in percents as:

$$
\mathrm{AA}=\left(\mathrm{D}_{\mathrm{x}}-\mathrm{D}_{\mathrm{o}}\right) \mathrm{D}_{\mathrm{x}} * 100(\%)
$$

in which $D_{x}$ - is the optic density, representing non-inhibited adrenaline autooxidation; $\mathrm{D}_{0}$ - is the optic density, representing the autooxidation of adrenaline in the presence of the investigated substances. The reference compound was cysteamine.

The impulse voltammetry lets generate the hydroxyl radicals and other ROS in water solutions on electrodes by the electrochemical way. The electrogenerated ROS may be a model 
of elementary redox stages in biological systems. The investigation of the interaction of the investigated compounds with the ROS includes the obtaining and analysis of the special differential voltammogram of molecular oxygen reduction in special impulse mode on cathodeanode. These voltammograms let reveal the reduction peak of the oxygen, hydrogen peroxide, and hydroxyl radicals. Also, it is possible to obtain on the platinum cathode the peaks of the reduction of the bivalent iron [18].

The electrochemical investigations were conducted by the universal polarography PU1 (USSR) in the mode of differential impulse voltammetry in three-electrode circuit $\mathrm{Me} / \mathrm{Pt} / \mathrm{Ag}$, $\mathrm{AgCl}$. The potential of the copper and platinum work electrode was given using the $\mathrm{Ag} \mid \mathrm{AgCl}$ reference electrode. The auxiliary electrode was a platinum spiral (potential scan rate of $105 \mathrm{mV} / \mathrm{s}$ ). The solutions of the compounds in $0,1 \mathrm{M} \mathrm{NaCl}$ were prepared before the proper experiments. The background electrolyte was obtained by the use of double-crystallized $\mathrm{NaCl}$ in bidistilled water. The iron ion concentration was $2,4 \mathrm{mM}$. The oxygen concentration was correspondent to the equilibrium of oxygen concentration in the conditions of normal pressures and the temperature $20{ }^{\circ} \mathrm{C}$. The conclusions about the antioxidant activities were made by the morphological changes of voltammograms [19].

\section{Results and Discussion}

Cysteine is a natural amino acid, which takes part in different enzyme processes, containing the mercapto group.

Table 1. The obtained S-(2-methylquinolin-4-yl)-1-cysteines and analogous substances.

\begin{tabular}{|c|c|c|c|c|c|c|c|}
\hline № & $\mathbf{R}_{1}$ & $\mathbf{R}_{2}$ & $\mathbf{R}_{3}$ & № & $\mathbf{R}_{1}$ & $\mathbf{R}_{2}$ & $\mathbf{R}_{3}$ \\
\hline $1 \mathrm{a}$ & $\mathrm{H}$ & $\mathrm{NH}_{2}$ & $\mathrm{COOH}$ & $2 \mathrm{~d}$ & $\mathrm{~F}$ & $\mathrm{H}$ & $\mathrm{COOH}$ \\
\hline $1 \mathrm{~b}$ & $\mathrm{OCH}_{3}$ & $\mathrm{NH}_{2}$ & $\mathrm{COOH}$ & $2 \mathrm{e}$ & $\mathrm{Cl}$ & $\mathrm{H}$ & $\mathrm{COOH}$ \\
\hline $1 \mathrm{c}$ & $\mathrm{OC}_{2} \mathrm{H}_{5}$ & $\mathrm{NH}_{2}$ & $\mathrm{COOH}$ & $2 f$ & $\mathrm{Br}$ & $\mathrm{H}$ & $\mathrm{COOH}$ \\
\hline $1 d$ & $\mathrm{~F}$ & $\mathrm{NH}_{2}$ & $\mathrm{COOH}$ & $2 \mathrm{~g}$ & $\mathrm{H}$ & $\mathrm{H}$ & $\mathrm{COOH}, \mathrm{HCl}$ \\
\hline $1 \mathrm{e}$ & $\mathrm{Cl}$ & $\mathrm{NH}_{2}$ & $\mathrm{COOH}$ & $2 \mathrm{~h}$ & $\mathrm{OCH}_{3}$ & $\mathrm{H}$ & $\mathrm{COOH}, \mathrm{HCl}$ \\
\hline $1 \mathrm{f}$ & $\mathrm{Br}$ & $\mathrm{NH}_{2}$ & $\mathrm{COOH}$ & $2 \mathrm{i}$ & $\mathrm{OC}_{2} \mathrm{H}_{5}$ & $\mathrm{H}$ & $\mathrm{COOH}, \mathrm{HCl}$ \\
\hline $1 \mathrm{~g}$ & $\mathrm{H}$ & $\mathrm{NH}_{2}$ & $\mathrm{COOH}, 2 \mathrm{HCl}$ & $2 j$ & $\mathrm{~F}$ & $\mathrm{H}$ & $\mathrm{COOH}, \mathrm{HCl}$ \\
\hline $1 \mathrm{~h}$ & $\mathrm{OCH}_{3}$ & $\mathrm{NH}_{2}$ & $\mathrm{COOH}, 2 \mathrm{HCl}$ & $2 \mathrm{k}$ & $\mathrm{Cl}$ & $\mathrm{H}$ & $\mathrm{COOH}, \mathrm{HCl}$ \\
\hline $1 \mathrm{i}$ & $\mathrm{OC}_{2} \mathrm{H}_{5}$ & $\mathrm{NH}_{2}$ & $\mathrm{COOH}, 2 \mathrm{HCl}$ & 21 & $\mathrm{Br}$ & $\mathrm{H}$ & $\mathrm{COOH}, \mathrm{HCl}$ \\
\hline $1 \mathrm{j}$ & $\mathrm{F}$ & $\mathrm{NH}_{2}$ & $\mathrm{COOH}, 2 \mathrm{HCl}$ & $2 m$ & $\mathrm{H}$ & $\mathrm{H}$ & $\mathrm{COONa}$ \\
\hline $1 \mathrm{k}$ & $\mathrm{Cl}$ & $\mathrm{NH}_{2}$ & $\mathrm{COOH}, 2 \mathrm{HCl}$ & $2 n$ & $\mathrm{OCH}_{3}$ & $\mathrm{H}$ & $\mathrm{COONa}$ \\
\hline 11 & $\mathrm{Br}$ & $\mathrm{NH}_{2}$ & $\mathrm{COOH}, 2 \mathrm{HCl}$ & 20 & $\mathrm{OC}_{2} \mathrm{H}_{5}$ & $\mathrm{H}$ & $\mathrm{COONa}$ \\
\hline $1 \mathrm{~m}$ & $\mathrm{H}$ & $\mathrm{NH}_{2}$ & $\mathrm{COONa}$ & $2 p$ & $\mathrm{~F}$ & $\mathrm{H}$ & $\mathrm{COONa}$ \\
\hline $1 n$ & $\mathrm{OCH}_{3}$ & $\mathrm{NH}_{2}$ & $\mathrm{COONa}$ & $2 q$ & $\mathrm{Cl}$ & $\mathrm{H}$ & $\mathrm{COONa}$ \\
\hline 10 & $\mathrm{OC}_{2} \mathrm{H}_{5}$ & $\mathrm{NH}_{2}$ & $\mathrm{COONa}$ & $2 r$ & $\mathrm{Br}$ & $\mathrm{H}$ & $\mathrm{COONa}$ \\
\hline $1 \mathrm{p}$ & $\mathrm{F}$ & $\mathrm{NH}_{2}$ & $\mathrm{COONa}$ & $2 \mathrm{~s}$ & $\mathrm{H}$ & $\mathrm{H}$ & $\mathrm{COOCH}_{3}$ \\
\hline $1 q$ & $\mathrm{Cl}$ & $\mathrm{NH}_{2}$ & $\mathrm{COONa}$ & $2 \mathrm{t}$ & $\mathrm{OCH}_{3}$ & $\mathrm{H}$ & $\mathrm{COOCH}_{3}$ \\
\hline $1 \mathrm{r}$ & $\mathrm{Br}$ & $\mathrm{NH}_{2}$ & $\mathrm{COONa}$ & $2 u$ & $\mathrm{OC}_{2} \mathrm{H}_{5}$ & $\mathrm{H}$ & $\mathrm{COOCH}_{3}$ \\
\hline $1 \mathrm{~s}$ & $\mathrm{H}$ & $\mathrm{NH}_{2}$ & $\mathrm{COOCH}_{3}, 2 \mathrm{HCl}$ & $2 \mathrm{v}$ & $\mathrm{F}$ & $\mathrm{H}$ & $\mathrm{COOCH}_{3}$ \\
\hline $1 \mathrm{t}$ & $\mathrm{OCH}_{3}$ & $\mathrm{NH}_{2}$ & $\mathrm{COOCH}_{3}, 2 \mathrm{HCl}$ & $2 w$ & $\mathrm{OC}_{2} \mathrm{H}_{5}$ & $\mathrm{H}$ & $\mathrm{COOCH}_{3}, \mathrm{HCl}$ \\
\hline $1 \mathrm{u}$ & $\mathrm{OC}_{2} \mathrm{H}_{5}$ & $\mathrm{NH}_{2}$ & $\mathrm{COOCH}_{3}, 2 \mathrm{HCl}$ & $2 x$ & $\mathrm{Cl}$ & $\mathrm{H}$ & $\mathrm{COOCH}_{3}, \mathrm{HCl}$ \\
\hline $1 \mathrm{v}$ & $\mathrm{F}$ & $\mathrm{NH}_{2}$ & $\mathrm{COOCH}_{3}, 2 \mathrm{HCl}$ & $3 a$ & $\mathrm{H}$ & $\mathrm{NH}_{2}$ & $\mathrm{H}, 2 \mathrm{HCl}$ \\
\hline $1 \mathrm{w}$ & $\mathrm{Cl}$ & $\mathrm{NH}_{2}$ & $\mathrm{COOCH}_{3}, 2 \mathrm{HCl}$ & $3 b$ & $\mathrm{OCH}_{3}$ & $\mathrm{NH}_{2}$ & $\mathrm{H}, 2 \mathrm{HCl}$ \\
\hline $1 \mathrm{x}$ & $\mathrm{Br}$ & $\mathrm{NH}_{2}$ & $\mathrm{COOCH}_{3}, 2 \mathrm{HCl}$ & $3 c$ & $\mathrm{OC}_{2} \mathrm{H}_{5}$ & $\mathrm{NH}_{2}$ & $\mathrm{H}, 2 \mathrm{HCl}$ \\
\hline $2 a$ & $\mathrm{H}$ & $\mathrm{H}$ & $\mathrm{COOH}$ & $3 d$ & $\mathrm{~F}$ & $\mathrm{NH}_{2}$ & $\mathrm{H}, 2 \mathrm{HCl}$ \\
\hline $2 \mathrm{~b}$ & $\mathrm{OCH}_{3}$ & $\mathrm{H}$ & $\mathrm{COOH}$ & $3 e$ & $\mathrm{Cl}$ & $\mathrm{NH}_{2}$ & $\mathrm{H}, 2 \mathrm{HCl}$ \\
\hline $2 c$ & $\mathrm{OC}_{2} \mathrm{H}_{5}$ & $\mathrm{H}$ & $\mathrm{COOH}$ & $3 f$ & $\mathrm{Br}$ & $\mathrm{NH}_{2}$ & $\mathrm{H}, 2 \mathrm{HCl}$ \\
\hline
\end{tabular}


The previous investigations have confirmed that its modification with quinoline moiety leads to the interesting, effective bio regulating substances (Table 1) [13-15].

The PASS-prediction has shown that the mentioned compounds may be used as antioxidants as free radical traps for ROS (Fig. 2). It was interesting that the antioxidant properties were characteristic only for 6-unsubstituted quinolines (compounds 1a, 2a, 2s, 3a) and quinolines with donor substituents (1b, 2b, 2t). Nevertheless, the presence of halogen leads to the disappearance of the antioxidant properties out of the spectrum of biological activities.

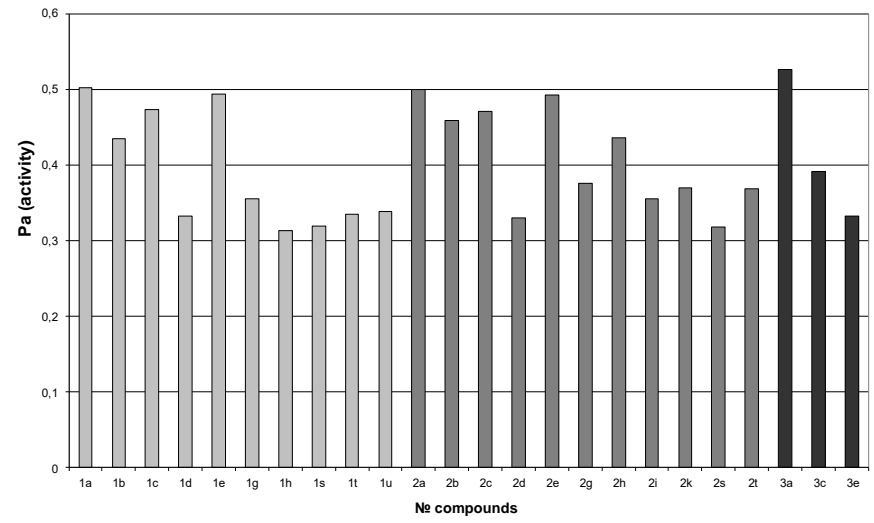

Figure 1. PASS-screening of the antioxidant properties of S-(2-methylquinolin-4-yl)-1-cysteine and its analogous compounds.

The radioprotective activity of L-cysteine derivatives was predictable (Fig. 3). Lcysteine, cysteamine, and their derivatives are known radioprotectors. The results of the screening of $\beta$-(quinolin-4-ylthio)-propionic acids $(2 \mathrm{a}-\mathrm{x})$, attract attention, as they possess the probability of radioprotective effects, similar to that of the S-(quinolin-4-yl)-1-cysteines (1a$\mathrm{x}$ ) and of S-(quinolin-4-yl)-cysteamines (compounds 3a-f). The most prominent for radioprotection effects are the compounds with non-blocked carboxyl and without substituents in the position six, or with donor substituent in it (compounds 1a-c, 1e, 2a-c, 2e).

The results of the virtual PASS-prediction and our own investigations, described in [1315] let us select three most effective (1i, 2i, 3c) compounds among the 54 4-thiol substituted quinolines. For them, the antioxidant and radioprotective action probability reach $47 \%$ (Fig. 2 and 3), which makes promising the investigation of the compounds $1 \mathrm{i}, 2 \mathrm{i}, 3 \mathrm{c}$. We have to pay attention that the screening includes membrane protection and the absence of negative effects - high toxicity, teratogenesis, carcinogenesis, mutagenesis, and embryotoxicity.

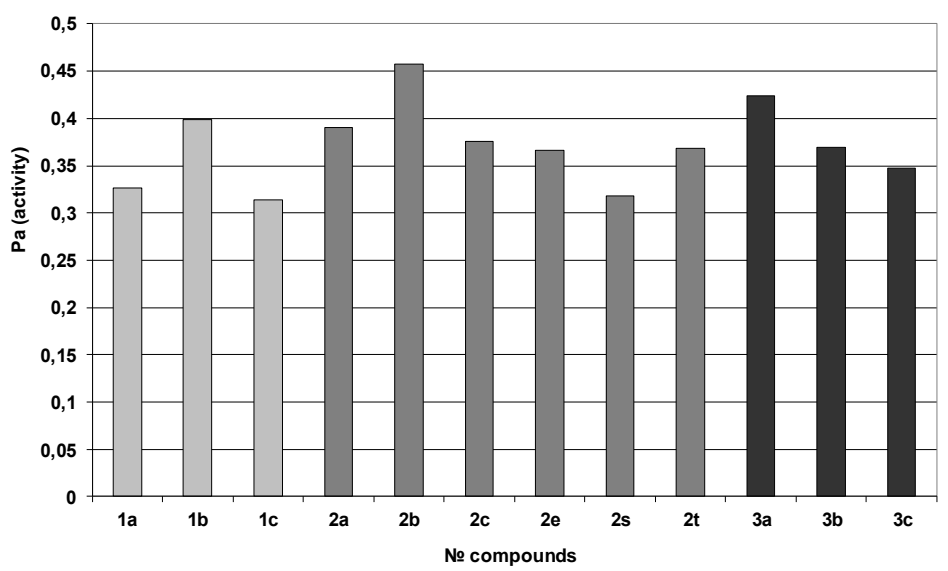

Figure 2. Computer screening of the radioprotection properties of S-(2-methylquinolin-4-yl)-1-cysteines and analogous compounds. 
We have to admit that the structure of the 4-thioquinolines $(1 \mathrm{i}, 2 \mathrm{i}, 3 \mathrm{c})$ is correspondent to the Lipinski requisite, defining the bioaccessibility of each compound by simple molecular criteria (molecular weight, molar refraction, lipophilicity, the number of the hydrogen bond donors and acceptors) [20].

The selected compounds were the most active in the primary screening models (Table. 2). We have to admit that in minor concentrations ( $25 \mathrm{MM})$, the compounds exceed the activity of the reference compound-cysteamine.

Table 2. The results of a priori spectrophotometric screening of 4-thioquinolines antioxidant properties.

\begin{tabular}{l|l|l} 
Compound number & $\mathbf{A A} * \mathbf{\%}(\mathbf{1 2 5} \mathbf{M M})$ & $\mathbf{A A}, \mathbf{\%}(\mathbf{2 5} \mathbf{M M})$ \\
\hline $\mathbf{1 i}$ & 29,0 & 21,0 \\
\hline $\mathbf{2 i}$ & 38,0 & 33,0 \\
\hline $\mathbf{3 c}$ & 47,0 & 42,0 \\
\hline Cysteamine (reference compound) & 62,0 & 15,0
\end{tabular}

A more profound investigation of antioxidant activities of the compounds was made by impulse voltammetry, capable of reproducing the process of the water radiolysis. The polarization of the copper cathode in impulse mode lets us distinguish the reduction peak of oxygen (II) by $\mathrm{E}=-0,6 \mathrm{~V}$, of hydrogen peroxide (III) by $\mathrm{E}=-1,1 \mathrm{~V}$, and hydroxyl radicals (I) by $\mathrm{E}=-0,2 \mathrm{~V}$, formed during the one-electron peroxide reduction:

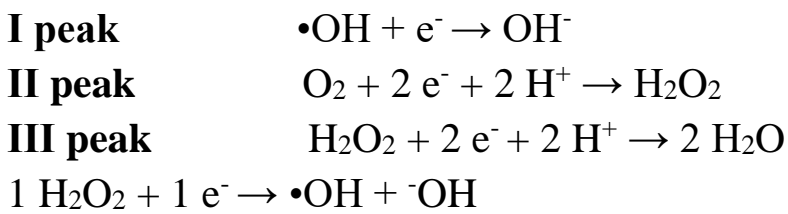

The changes in morphology and quantitative changes in each voltammogram during the addition of the compounds in the background electrolyte let us evaluate the character, and a degree of the interaction of the compounds with oxygen and ROS formed during its reduction [16].

In the reactions of the oxygen one-electron reduction in biosystems, a transition-metal ion usually takes part. It is used as a donor of the acceptor of one electron. So, preventive antioxidant action is very important. They react with the bivalent iron ions, which cause the formation of the most aggressive ROS-hydroxyl radicals [14]. In order to detect the possibility of the use as a preventive antioxidant, the compounds were tested during the oxidation of bivalent iron on a platinum electrode (Fig. 4, 6, 8). The last process may be considered equivalent to electro-Fenton [21-28].

The compound 1i, containing in its structure carboxy and amino group, influences all the oxygen reduction peaks on copper (Fig. 3). If the concentration is equal to $0,2 \cdot 10^{-3} \mathrm{~mol}^{-1}$, the peaks I and III reduce their intensity to $\mathrm{H} / \mathrm{H}_{0}=0,8$, and the peak II is slightly enhanced and shifted to more cathodic values. When the concentration is equal to $0,38 \cdot 10^{-3} \mathrm{~mol}^{-1}$, the peak I enhanced, the III peak remains on the same level, yet the peak II diminishes, and its shift to more positive potentials is observed. The subsequent increase of the concentration of the compound leads to the maximal reduction of the peaks I and III $\left(\mathrm{H} / \mathrm{H}_{0}\right.$, if C $=0,9 \cdot 10^{-3} \mathrm{~mol} \mathrm{l}^{-1}$ is equal, correspondently, to 0,45 and 0,35 ). If the concentration is $1,07 \cdot 10^{-3} \mathrm{~mol}^{-1}$, the peak III doesn't exist.

The differential voltammogram of the $1 \mathrm{i}$ compound, measured on the platinum cathode (Fig. 4) in the presence of $\mathrm{Fe}^{2+}\left(\mathrm{C}=2,42 \cdot 10^{-3} \mathrm{~mol} \mathrm{l}^{-1}\right)$, we may see that the presence of the compounds makes the $\mathrm{Fe}^{2+}$ oxidation peak reduce in the concentration of $0,099 \cdot 10^{-3} \mathrm{~mol}^{-1}$, yet if the concentration of the compound is equal to $0,57 \cdot 10^{-3} \mathrm{~mol}^{-1}$ a new peak, correspondent 
to the presence of $\mathrm{Fe}^{3+}$, appears. So, the compound $1 \mathrm{i}$ may be considered a preventive antioxidant.

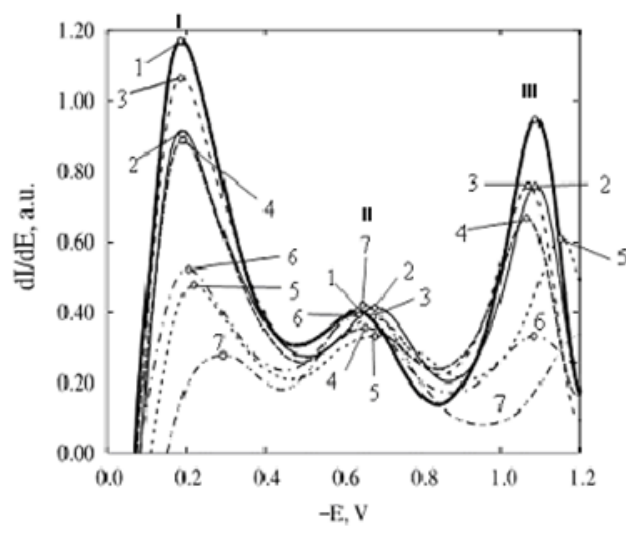

Figure 3. The differential voltammogram of the oxygen reduction on copper in the presence of different concentrations (2-6) of the compound $\mathbf{1 i}$ :

1 - background $0,1 \mathrm{M} \mathrm{NaCl}$;

$2-0,2 ; 3-0,38 ; 4-0,57 ; 5-0,74$; $6-0,90 ; 7-1,07 \mathrm{mM}$.

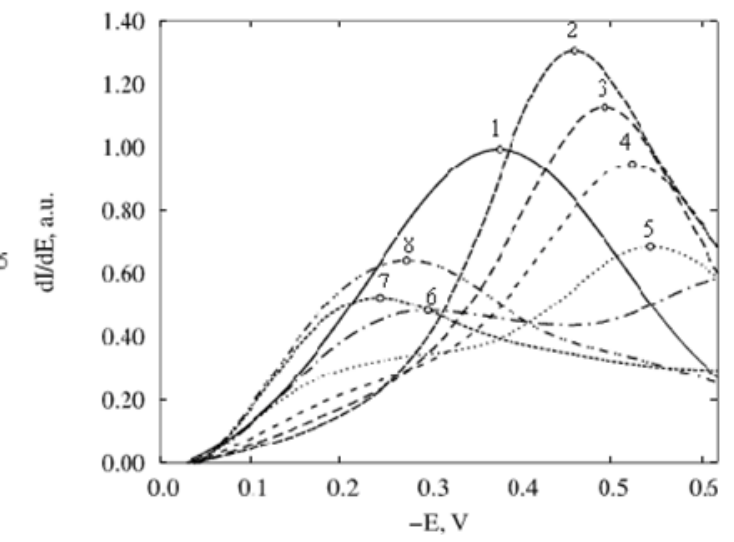

Figure 4. The differential voltammograms of the oxygen reduction on platinum in the background of $0,1 \mathrm{M} \mathrm{NaCl}$ in water (1), containing $\mathrm{Fe}^{2+}(2-2,42)$, in different concentrations of the compound $\mathbf{1 i}$ : $3-0,09 ; 4-0,20 ; 5-0,38 ; 6-0,56$, $7-0,74 ; 8-0,9 \mathrm{mM}$.

The compound $2 \mathrm{i}$, which contains only carboxy group in its structure, begins influencing the peak I beginning on the concentration of $0,60 \cdot 10^{-3} \mathrm{~mol} \mathrm{l}^{-1}$, yet the peak II firstly becomes more intensive if the potential is shifted to more positive values, and then it is reduced, and the value of the potential is returned to the initial value (Fig. 6). The intensity of the peak III is reduced proportionally to the compound concentration increase. Nevertheless, its maximal value for $\mathrm{H} / \mathrm{H}_{\mathrm{o}}$, which is equal to 0,45 , for the peaks I and III, is achieved for higher concentrations of $2 \mathrm{i}$ than for $1 \mathrm{i}$.

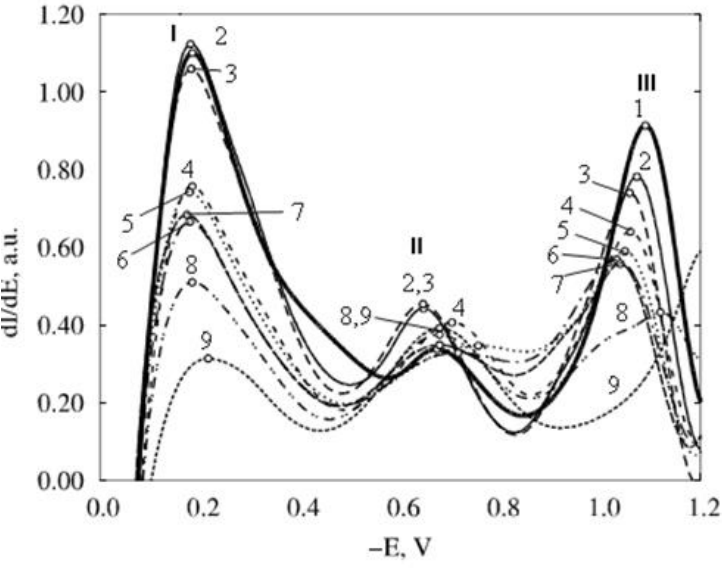

Figure 5. The differential voltammograms of the oxygen reduction on copper in different concentrations (2-6) of $2 \mathbf{i}: 1$ - background: $0,1 \mathrm{M}$

$\mathrm{NaCl} ; 2-0,19 ; 3-0,38 ; 4-0,60$

$5-0,74 ; 6-0,90 ; 7-1,07 ; 8-1,23$; $9-1,37 \mathrm{MM}$.

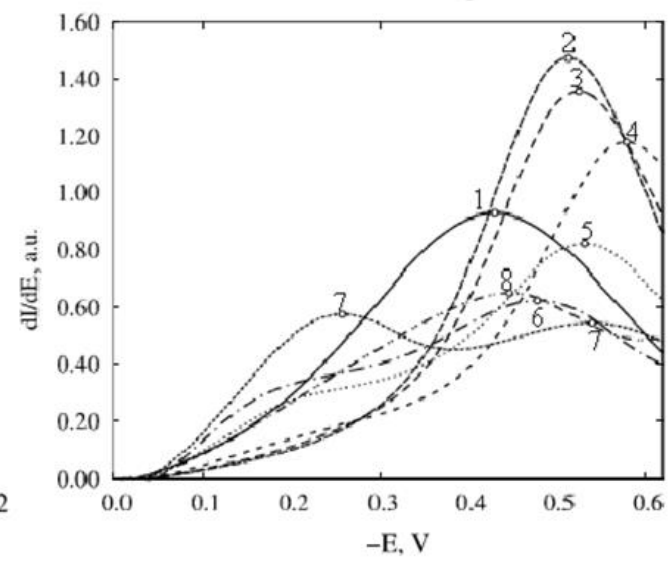

Figure 6. The differential voltammograms for the oxygen reduction on platinum in the background electrolyte $0,1 \mathrm{M} \mathrm{NaCl}$ in water (1), containing the ions $\mathrm{Fe}^{2+}(2-2,42)$, with the different concentrations of $2 \mathbf{i}: 3-0,09$;

$4-0,20 ; 5-0,38 ; 6-0,57,7-0,74$; $8-0,91 \mathrm{MM}$.

The voltammetric investigation of the influence of $2 \mathrm{i}$ on $\mathrm{Fe}^{2+}$ oxidation peak shows that it may also be considered a preventive antioxidant (Fig. 6).

Even in the lowest concentration $\left(\mathrm{C}=0,19 \cdot 10^{-3} \mathrm{~mol} \mathrm{l}^{-1}\right)$ of $3 \mathrm{c}$, containing an amino group, the height of the peaks I and III reduces significantly, yet the height of II is highly 
enhanced and remains on the same level in all the investigated concentration range (Fig. 7). The maximal decrease of the peak I is observed in the concentration of $0,38 \cdot 10^{-3} \mathrm{~mol}^{-1}$. The peak III is reduced if the concentration of the compound increases to $0,60 \cdot 10^{-3} \mathrm{~mol}^{-1}$; yet the further increase of the concentration of the compound makes the peak III disappear.

The differential voltammogram obtained on the platinum electrode (Fig. 8) shows that the compound $3 \mathrm{c}$ reduces the $\mathrm{Fe}^{2+}$ oxidation peak proportionally to its concentration. At the same time, the wave potential is shifted to more cathodic potential values. If the concentration is equal to $0,57 \cdot 10^{-3} \mathrm{~mol}^{-1}$, a peak of $\mathrm{Fe}^{3+}$ appears and increases. So, the compound $3 \mathrm{c}$ may be considered a preventive antioxidant.

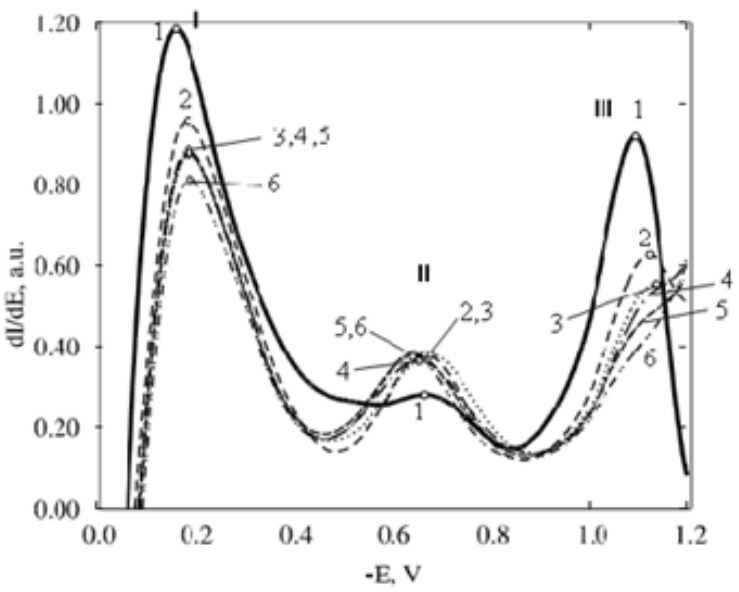

Figure 7. Differential voltammograms of oxygen reduction on copper in the presence of different concentrations (2-6) of 3c:

1 - background $0,1 \mathrm{M} \mathrm{NaCl} ; 2-0,19$;

$3-0,38 ; 4-0,57 ; 5-0,74 ; 6-0,90 \mathrm{MM}$.

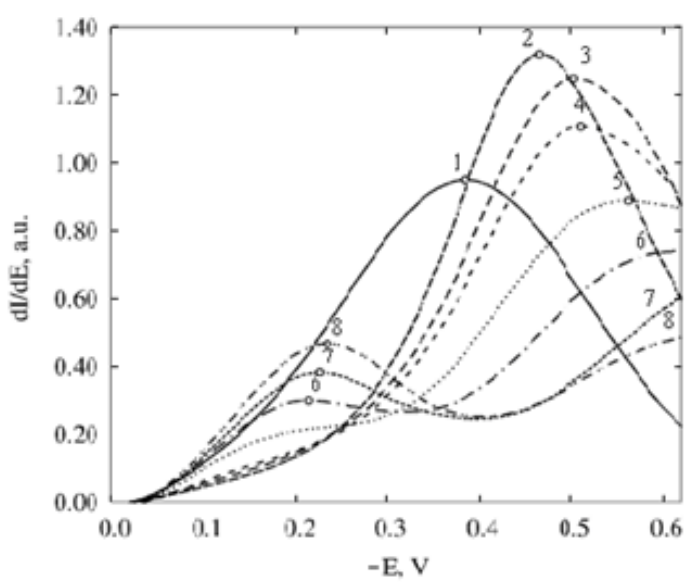

Figure 8. The differential voltammograms of the oxygen reduction on platinum in the background of $0,1 \mathrm{M} \mathrm{NaCl}$ in water (1), containing $\mathrm{Fe}^{2+}(2-2,42)$, with different concentrations of 3c: $3-0,09 ; 4-$ 0,$20 ; 5-0,38 ; 6-0,57,7-0,74 ; 8-0,91$ мM.

Analyzing the influences of the concentrations of all of the mentioned compounds on the electrochemical behavior, represented by voltammograms, we may make the next observations:

The compound $3 \mathrm{c}$ is more effective in the hydroxyl radical suppression in lower concentrations $0,19-0,38 \cdot 10^{-3} \mathrm{~mol}^{-1}$, yet the compounds $1 \mathrm{i}$ and $2 \mathrm{i}$ act with higher concentrations.

The oxygen reduction (peak II) in all concentration range is facilitated efficiently by $3 \mathrm{c}$, yet the compound $2 \mathrm{i}$ is most efficient only in the concentration range of $0,19-0,38 \cdot 10^{-3} \mathrm{~mol}$ $1^{-1}$.

The $3 \mathrm{c}$ compound is the most effective e in the reduction of the peak III (hydrogen peroxide formation); the compounds $1 \mathrm{i}$ and $2 \mathrm{i}$ also have an antioxidant effect, but they influence the peak nearly equally.

\section{Conclusions}

From the antioxidant activity spectrochemical and electrochemical test of three novel quinolinic derivatives, it was possible to conclude that: The compounds manifest significant antioxidant activity, and their activity, in low concentration, is higher than that of the reference compound - cysteamine; The antioxidant activity investigation by impulse voltammetry confirmed the high antioxidant activity of the investigated compounds. They are considered preventive antioxidants; The compound $3 \mathrm{c}$ was the most efficient antioxidant, acting with all 
the peaks of reacting oxygen species generation; It confirms the availability of the tested compounds as efficient radioprotectors.

\section{Funding}

This research received no external funding.

\section{Acknowledgments}

This research has no acknowledgment.

\section{Conflicts of Interest}

The authors declare no conflict of interest.

\section{References}

1. Akbar Boojar, M.M. An Overview of the Cellular Mechanisms of Flavonoids Radioprotective Effects. Adv. Pharm. Bull 2020, 10, 13-19, https://doi.org/10.15171/apb.2020.002.

2. Girdhani, S.; Sachs, S.; Hlatky, L. Biological effects of proton radiation: an update. Radiat. Prot. Dosimetry 2015, 166, 334-338, https://doi.org/10.1093/rpd/ncv178

3. Islam, M.T. Radiation interactions with biological systems. International Journal of Radiation Biology 2017, 93, 487-493, https://doi.org/10.1080/09553002.2017.1286050.

4. Unuofin, J.O.; Lebelo, S.L. Antioxidant Effects and Mechanisms of Medicinal Plants and Their Bioactive Compounds for the Prevention and Treatment of Type 2 Diabetes: An Updated Review. Oxidative medicine and cellular longevity 2020, 2020, 1356893-1356893, https://doi.org/10.1155/2020/1356893.

5. Ali, S.S.; Ahsan, H.; Zia, M.K.; Siddiqui, T.; Khan, F.H. Understanding oxidants and antioxidants: Classical team with new players. Journal of Food Biochemistry 2020, 44, 131-145, https://doi.org/10.1111/jfbc.13145.

6. Bazine, I.; Cheraiet, Z.; Bensegueni, R.; Bensouici, C.; Boukhari, A. Synthesis, antioxidant and anticholinesterase activities of novel quinoline-aminophosphonate derivatives. Journal of Heterocyclic Chemistry 2020, 57, 2139-2149, https://doi.org/10.1002/jhet.3933.

7. Zeleke, D.; Eswaramoorthy, R.; Belay, Z.; Melaku, Y. Synthesis and Antibacterial, Antioxidant, and Molecular Docking Analysis of Some Novel Quinoline Derivatives. Journal of Chemistry 2020, 2020, 1-16, https://doi.org/10.1155/2020/1324096.

8. Ferreira, J.P.S.; Cardoso, S.M.; Almeida Paz, F.A.; Silva, A.M.S.; Silva, V.L.M. Synthesis of 2aroylfuro[3,2-c]quinolines from quinolone-based chalcones and evaluation of their antioxidant and anticholinesterase activities. New Journal of Chemistry 2020, 44, 6501-6509, https://doi.org/10.1039/D0NJ00409J

9. Douadi, K.; Chafaa, S.; Douadi, T.; Al-Noaimi, M.; Kaabi, I. Azoimine quinoline derivatives: Synthesis, classical and electrochemical evaluation of antioxidant, anti-inflammatory, antimicrobial activities and the

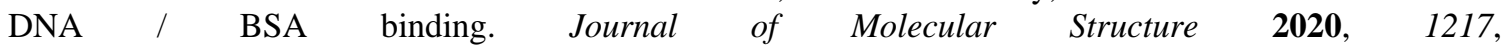
https://doi.org/10.1016/j.molstruc.2020.128305.

10. Taman, A.; Alhusseiny, S.M.; Saleh, N.E.; Youssef, M.Y.; Mansour, B.; Massoud, M.; El-Beshbishi, S.N. Effect of a newly synthesized quinoline-based compound (PPQ-8) on murine schistosomiasis mansoni. Journal of Helminthology 2020, 94, https://doi.org/10.1017/S0022149X2000005X.

11 Khodia, I.A.; Boulebd, H. Synthesis, biological evaluation, theoretical investigations, docking study and ADME parameters of some 1,4-bisphenylhydrazone derivatives as potent antioxidant agents and acetylcholinesterase inhibitors,Mol. Divers.; 2020, 2020, 10064-10068, https://doi.org/10.1007/s11030020-10064-8

12. Zoonish, M.; Arif-Ullah, K.; Muhammad, F.; Muhammad, Z.D.; Humaira, N.; Sameen, F.A.; Madeeha, M. Molecular Docking, Antioxidant, Anticancer and Antileishmanial Effects of Newly Synthesized Quinoline Derivatives. Anti-Cancer Agents in Medicinal Chemistry 2020, 20, 1516-1529, http://dx.doi.org/10.2174/1871520620666200516145117.

13. Brazhko, O.A.; Omelyanchik, L.O.; Zavgorodniy, M.P.; Martynovsky, M.P. Chemistry and biological activity 2(4)-thioquinolines and 9-thioacridines. Zaporizhzhya: ZNU, in Ukrainian 2013.

14. Omelyanchik, L.O.; Brazhko, O.A.; Zavgorodniy, M.P.; Petrusha, Y. Synthesis, physical and chemical properties and biological activity of $\mathrm{N}$ - and S-substituted six-membered nitrogen-containing heterocycles. Zaporozhye: ZNU,Edition in Ukrainian 2016. 
15. Brazhko, O.A.; Kornet, M.M.; M. P. Zavgorodniy, Pat. 97937 Ukraine, IPC C07D 215/36, C07D 219/04, C07D 221/06, C07D 221/16, C07D 319/14. No. 2011 11474; stated. 28.09.2011; published March 26, 2012 Bull No. $6.10 \mathrm{p}$

16. Filimonov, D.A.; Lagunin, A.A.; Gloriozova, T.A.; Rudik, A.V.; Druzhilovskii, D.S.; Pogodin, P.V.; Poroikov, V.V. Prediction of the Biological Activity Spectra of Organic Compounds Using the Pass Online Web Resource. Chemistry of Heterocyclic Compounds 2014, 50, 444-457, https://doi.org/10.1007/s10593014-1496-1.

17. Yelenich, I.P.; Rassukana, Y.; Khomutnyk, Y.; Kornet, M.; Brazhko, A.; Syntasa, A.D.; Onys'ko, P. Synthesis, The Antioxidant and Antibacterial Activity of Fluoroalkyl Substituted Thiazolidin ones and Thiazinanones, incorporating an aminophosphonate or aminocarboxylate fragment. J. Org. Pharm. Chem. 2011, 47, 45-50, article in Ukrainian, https://doi.org/10.24959/ophcj.14.814.

18. Shapoval, G.S.; Kruglyak, O.S. Electrochemical modeling of antioxidants action and determination of their activity. Russian Journal of General Chemistry 2011, 81, https://doi.org/10.1134/S1070363211070073.

19. Shapoval, G.S.; Kruglyak, O.S. Redox-reactions of active oxygen species on the surface of model biomembranes. Russian Journal of General Chemistry 2013, 83, 1503-1510, https://doi.org/10.1134/S1070363213080057.

20. Lipinski, C.A.; Lombardo, F.; Dominy, B.W.; Feeney, P.J. Experimental and computational approaches to estimate solubility and permeability in drug discovery and development settings. Advanced Drug Delivery Reviews 1997, 23, 3-25, https://doi.org/10.1016/S0169-409X(96)00423-1..

21. Lee, J.; Son, A.; Ko, Y.-J.; Shin, M.-J.; Kim, W.S.; Choi, J.W.; Lee, J.; Hong, S.W. Investigation of titanium mesh as a cathode for the electro-Fenton process: consideration of its practical application in wastewater treatment. Environmental Science: Water Research \& Technology 2020, 6, 1627-1637, https://doi.org/10.1039/C9EW01144G.

22. He, J.; Li, N.; Zhang, D.; Zheng, G.; Zhang, H.; Yu, K.; Jiang, J. Real-time monitoring of ciprofloxacin degradation in an electro-Fenton-like system using electrochemical-mass spectrometry. Environmental Science: Water Research \& Technology 2020, 6, 181-188, https://doi.org/10.1039/C9EW00868C.

23. Matyszczak, G.; Krzyczkowska, K.; Fidler, A. A novel, two-electron catalysts for the electro-Fenton process. Journal of Water Process Engineering 2020, 36, https://doi.org/10.1016/j.jwpe.2020.101242

24. Zou, R.; Angelidaki, I.; Jin, B.; Zhang, Y. Feasibility and applicability of the scaling-up of bio-electroFenton system for textile wastewater treatment. Environment International 2020, 134, https://doi.org/10.1016/j.envint.2019.105352.

25. Avinash Chunduri, L.A.; Madhusudhana Rao, K.; Vijaya, S.K.; Kurdekar, A.D.; Prathibha, C.; Kamisettim V. Influence of Surface Charge on the Functional Properties of Silica Nanoparticles and Cellular Toxicity. Lett. Appl. NanoBioSci. 2020,3, 1225-1238, https://doi.org/10.33263/LIANBS93.12251238.

26. Jumbad, V.R.; Chel, A.; Verma, U.; Kaushik, G. Application of Electrolytic Plasma Process in Surface Improvement of Metals: A Review. Lett. Appl. NanoBioSci. 2020, 3, 1249-1262, https://doi.org/10.33263/LIANBS93.12491262.

27. Guelfi, D.R.V.; Gozzi, F.; Sirés, I.; Brillas, E.; Machulek, A.; de Oliveira, S.C. Antituberculosis drug isoniazid degraded by electro-Fenton and photoelectro-Fenton processes using a boron-doped diamond anode and a carbon-PTFE air-diffusion cathode. Environmental Science and Pollution Research 2019, 26, 4415-4425, https://doi.org/10.1007/s11356-018-2024-0.

28. daSilva, L.M.; Gozzi, F.; Cavalcante, R.P.; de Oliveira, S.C.; Brillas, E.; Sirés, I.; Machulek Jr, A. Assessment of 4-Aminoantipyrine Degradation and Mineralization by Photoelectro-Fenton with a BoronDoped Diamond Anode: Optimization, Treatment in Municipal Secondary Effluent, and Toxicity. ChemElectroChem 2019, 6, 865-875, https://doi.org/10.1002/celc.201801651. 